\title{
Monocyte platelet aggregates in children with Kawasaki disease- a preliminary study from a tertiary care centre in North-West India
}

Pandiarajan Vignesh ${ }^{1 *}$, Amit Rawat ${ }^{1}$, Jitendra Kumar Shandilya ${ }^{1}$, Man Updesh Singh Sachdeva², Jasmina Ahluwalia ${ }^{2}$ and Surjit Singh ${ }^{1 *}$

\begin{abstract}
Background: Platelet activation is an integral part of pathogenesis of Kawasaki disease (KD). However, there is paucity of literature on flow-cytometry based assessment of platelet activation in KD. We aimed to analyse monocyte-platelet aggregates (MPAs), one of the sensitive markers for platelet activation, by flow cytometry in children with KD.

Findings: In this single-centre prospective study, we have enrolled 14 children with KD and results were compared with age-matched febrile $(n=15)$ and healthy $(n=13)$ controls. After gating monocytes in side-scatter plot, MPAs were identified based on CD14 and CD41 expression. Two (2) $\mathrm{ml}$ of blood samples for children with KD were collected at 3 phases of illness- acute stage before start of intravenous immunoglobulin or aspirin, $24 \mathrm{~h}$ after completion of IVlg infusion, and 3 months after acute episode of KD.

Children with KD had a significantly higher MPA\% values [Median (IQR)- 41.3\% $(26.6,52.7)]$ when compared with febrile [Median (IQR)- 5.98\% (2.98-9.72)] and normal [Median (IQR)- 4.48\% (2.57-5.59)] controls, $p<0.01$. On follow-up, the MPA\% showed a gradual decline in children with KD, but even at 3 months, the value [Median (IQR)- $7.55 \%$ (4.15-14.6)] was higher compared to healthy controls [Median (IQR)- 4.48\% (2.57-5.59)].
\end{abstract}

Conclusions: Our results suggest that MPA\% was significantly elevated in acute stages in children with KD and activated platelets may continue to persist even after systemic inflammation has subsided. Future studies are warranted whether objective evidence of platelet activation may guide the use of immunomodulatory and antiplatelet therapy in KD.

Keywords: Kawasaki Disease, Platelet activation, Monocyte platelet aggregates, Flow cytometry, India

\footnotetext{
*Correspondence: vigimmc@gmail.com; surjitsinghpgi@rediffmail.com

${ }^{1}$ Allergy Immunology Unit, Department of Pediatrics, Advanced Pediatrics

Centre, Postgraduate Institute of Medical Education and Research, 160012

Chandigarh, India

Full list of author information is available at the end of the article
}

(c) The Author(s). 2021 Open Access This article is licensed under a Creative Commons Attribution 4.0 International License, which permits use, sharing, adaptation, distribution and reproduction in any medium or format, as long as you give appropriate credit to the original author(s) and the source, provide a link to the Creative Commons licence, and indicate if changes were made. The images or other third party material in this article are included in the article's Creative Commons licence, unless indicated otherwise in a credit line to the material. If material is not included in the article's Creative Commons licence and your intended use is not permitted by statutory regulation or exceeds the permitted use, you will need to obtain permission directly from the copyright holder. To view a copy of this licence, visit http://creativecommons.org/licenses/by/4.0/. The Creative Commons Public Domain Dedication waiver (http://creativecommons.org/publicdomain/zero/1.0/) applies to the data made available in this article, unless otherwise stated in a credit line to the data. 


\section{Introduction}

Kawasaki disease (KD) is a multi-systemic vasculitis that predominantly affects young children [1]. It is considered to be the most frequent cause of acquired heart disease in children in developed countries. Hospital-based data from our centre have also shown a sustained increase in number of cases of KD since the mid-1990 s [2]. Although over 50 years have passed since Dr Tomisaku Kawasaki first reported a case series of this disease, its etiology remains unknown [1]. Approximately $15-25 \%$ of patients with KD may develop coronary artery abnormalities (CAAs) including dilatations and aneurysms if the diagnosis is missed or delayed and treatment not initiated in time. Prompt therapy during the acute phase of disease with intravenous immunoglobulin (IVIg) results in a marked decrease in incidence of CAAs [1].

Vasculitis of systemic small- and medium-sized arteries, especially the coronary arteries, is the main pathological finding in KD and this can result in endothelial cell damage and platelet activation. Activated platelets can in turn secrete several chemokines (platelet factor 4, CXCL5, IL-8, CXCL-7, CCL5, CCL7) and enhance inflammation in vascular walls $[3,4]$. Platelet activation is, therefore, considered to play an essential role in pathogenesis of KD.

Markers of platelet activation such as leukocyteplatelet aggregates and P-selectin expression are elevated in coronary artery disease (CAD) and are implicated in progression of cardiovascular events [5]. Among all leukocytes, monocytes have the highest affinity towards platelets to form aggregates [6]. Monocyte-platelet aggregates (MPAs) are even considered a better marker for activated platelets than P-selectin expression [6]. Occurrence of coronary thrombosis and premature arteriosclerosis in KD suggests that excess activation of platelets and coronary vasculitis may play an important role in progression of vascular damage in KD. Though platelet activation has been studied in KD, there is paucity of literature on flow cytometry-based assessment of leukocyte-platelet aggregates in $\mathrm{KD}$ and there are no data from developing countries [7-13].

\section{Findings}

\section{Materials and Methods}

Children with KD diagnosed in the Allergy Immunology Unit, Advanced Pediatrics Centre, Postgraduate Institute of Medical Education and Research, Chandigarh, India, from July 2015 to December 2016 were enrolled. Written informed consent was obtained from parents. Diagnosis of $\mathrm{KD}$ was based on the American Heart Association (AHA) criteria [1]. Age and sex-matched febrile children who had a diagnosis other than KD were taken as febrile controls. Siblings nearest in age to index patient were taken as healthy controls. In cases where a sibling control was not available or accessible, an agematched control was enrolled from outpatient clinics.

The Institute Thesis Committee and the Institute Ethics Committee approved the study protocol. The Departmental Review Board has approved the manuscript. Standard treatment protocols were followed for management of KD [1].

\section{Sample collection}

Venepuncture was carried out under aseptic conditions and with minimal occlusion. Two (2) $\mathrm{ml}$ of peripheral venous blood was withdrawn into a vacutainer containing $0.106 \mathrm{~mol} / \mathrm{L}$ of trisodium citrate (blood-citrate ratio 9:1) after discarding initial $1 \mathrm{ml}$ of sample. Samples were collected at three different phases in children with KDacute stage before administration of IVIg and aspirin; $24 \mathrm{~h}$ after administration of IVIg; and approximately 3 months after onset of illness. Febrile and healthy controls had their blood drawn only once in an identical manner.

\section{Measurement of monocyte-platelet aggregates}

Blood samples were processed as quickly as possible (within $2 \mathrm{~min}$ ) to avoid time-dependent spontaneous aggregation and activation of platelets. Vortexing, centrifugation, and stirring were avoided before fixation of platelets. Fixation of cells and erythrocyte lysis was carried out at room temperature using Becton Dickinson FACS ${ }^{\odot}$ lysing solution. After $10 \mathrm{~min}$ of incubation, samples were washed with phosphate-buffered saline and immuno-labelled with appropriate quantities of fluorescein isothiocyanate (FITC) conjugated GP IIb (CD41, BD Pharmingen ${ }^{\mathrm{Tm}}$, Catalogue no.555,466) and PerCPconjugated CD14 (BD Pharmingen ${ }^{\mathrm{\tau m}}$, Catalogue no.555, 398) antibodies. After incubation for $20 \mathrm{~min}$ at room temperature, cells were acquired on a flow cytometer (Beckman Coulter, Navios). Using Kaluza ${ }^{\odot}$ software, monocytes were gated from lymphocyte side scatter plot. MPAs were identified from monocyte population that expressed both CD14 and CD41 [Fig. 1].

Assessment of MPAs is subject to in vitro platelet activation, and there is a chance for falsely elevated levels of MPAs as a result of this activation. The experiment was carried out initially in 10 healthy controls for standardization of the methodology. Several steps done to prevent in vitro platelet activation include collection of free flow blood without squeezing, immediate fixation of platelets, and minimizing the steps of vortexing and centrifugation during analysis. Efforts were put in to ensure that these precautions were observed during the conduct of this study. Standardization assays were also performed to find out the most appropriate quantity of antibody and the required time for incubation for red cell lysis. During standardization, samples were processed with increasing 


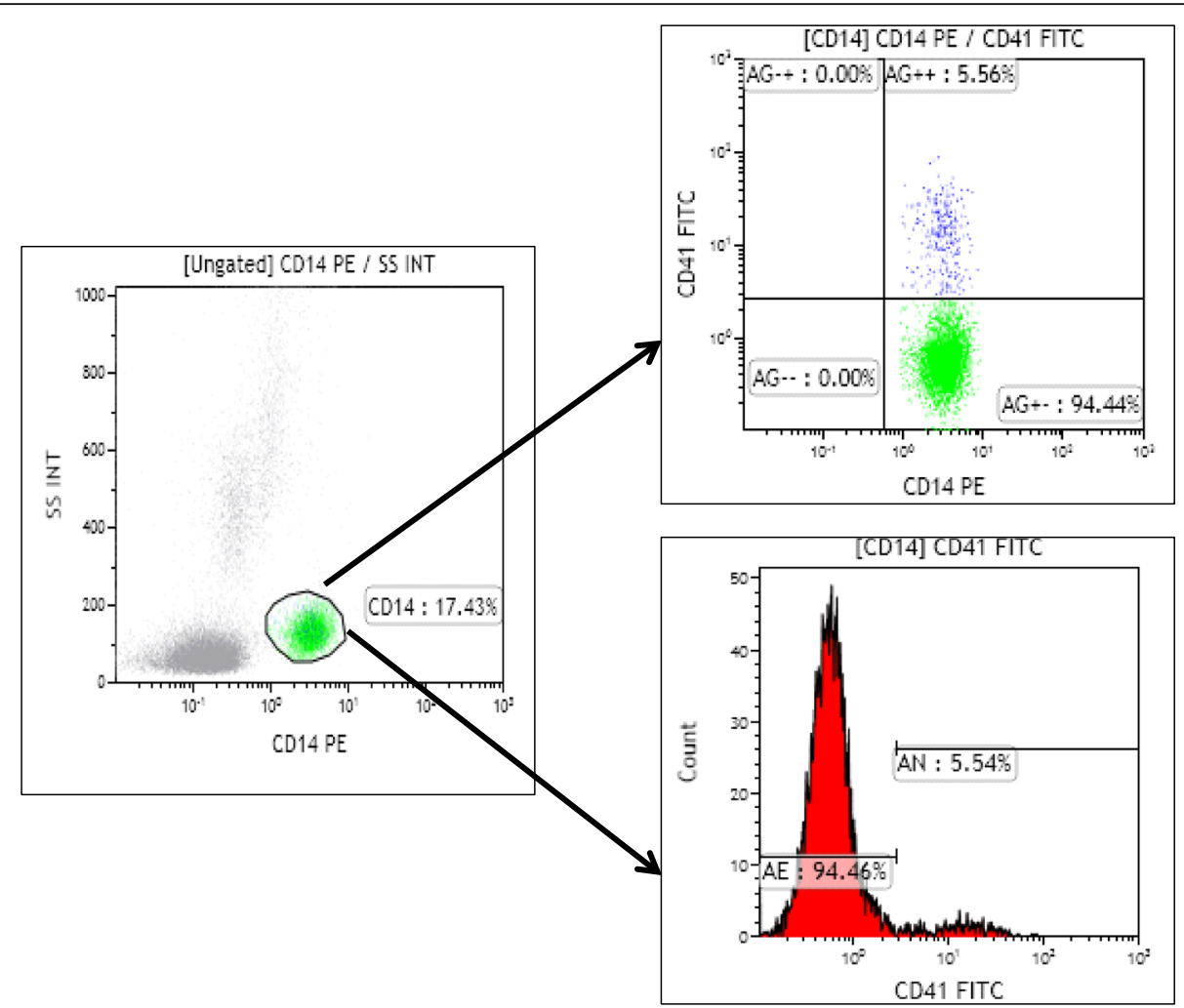

Fig. 1 Representative flow cytometry plots that demonstrate gating of monocytes from the side scatter plot of lymphocytes, and analysis of MPA\% by identifying monocyte populations that express both CD14 and CD41

quantities of antibodies (i.e. $5 \mu \mathrm{L}, 8 \mu \mathrm{L}, 10 \mu \mathrm{L}, 15 \mu \mathrm{L}$, and $20 \mu \mathrm{L}$ ) and $8 \mu \mathrm{L}$ of antibody was found to yield appropriate results.

\section{Statistical analysis}

Means were compared using unpaired student ' $\mathrm{t}$ ' test and analysis of variance (ANOVA). Medians were compared using Mann-Whitney U test and Kruskal Wallis test. Categorical variables were compared by Fisher exact test. A 2-tailed p-value less than 0.05 was considered significant. Statistical analysis was performed with SPSS statistical software version 20.0 (SPSS Inc., Chicago, IL, USA).

\section{Results}

Fourteen [14] children with KD were enrolled during the study period. Fifteen [2] children were taken as febrile controls and 13 as healthy controls. Presumed aetiology of fever in febrile controls was viral upper respiratory tract infections [5], enteric fever [5], staphylococcal abscesses [3], and pneumonia [2]. Median age (interquartile range (IQR)) in cases, febrile controls, and normal controls was 6 (3.0-7.25), 5 (3.6-9.0), and 5.5 (4.15-6.5) years, respectively. Male to female ratio among the 3 groups was 12:2, $13: 2$, and 11:2, respectively. Median duration of fever in febrile controls was 9 days (range: 5-14 days), which is significantly lower than median duration of fever in children with KD, 13.5 days (range: $7-21$ days), $p=0.024$. (Table 1 ). Two children had transient coronary artery abnormalities (CAAs) in form of brightness of coronary arteries and coronary ectasia. One child (7-month-old boy) developed giant coronary aneurysms in left main, left anterior descending, and right coronary arteries. All patients received IVIg $(2 \mathrm{~g} / \mathrm{kg})$ infusion for treatment for KD. Two patients also received IV infliximab infusion $(5 \mathrm{mg} / \mathrm{kg}$ ) - one child with giant coronary artery aneurysm and the other with

Table 1 Baseline clinical and laboratory characteristics of children with Kawasaki disease at enrolment $(n=14)$

\begin{tabular}{ll}
\hline Clinical parameter & Result \\
\hline Median age (IQR) & 6 years $(3.0,7.25)$ \\
Male: Female & $12: 2$ \\
Duration of fever [median (IQR)] & 13.5 days $(8.0,15.0)$ \\
No. of cases with incomplete KD (\%) & $5(35.7 \%)$ \\
Hemoglobin in g/dL [median (IQR)] & $9.2(7.6,11.3)$ \\
White cell counts (x 109/L) [median (IQR)] & $14.15(10.6,21.2)$ \\
Absolute neutrophil counts (x 109/L) [median (IQR)] & $7.9(6.2,12.4)$ \\
Platelet counts (x 10 $/ \mathrm{L})[$ median (IQR)] & $385.5(233.5,598.5)$ \\
Erythrocyte sedimentation rate at 1st hour (mm) & $45(28.5,69.5)$ \\
[median (IQR)] & $48.5(23,81.8)$ \\
C-reactive protein in mg/L [median (IQR)] &
\end{tabular}

$I Q R$ Inter-quartile range; $K D$ Kawasaki disease 
severe systemic disease and transient CAA. Antiplatelet dose of aspirin was continued for 3 months in one child as he persisted in having elevated platelet counts $\left(640 \times 10^{9} /\right.$ $\mathrm{L})$.

MPA\% values were significantly high in cases [Median (IQR)- $41.3 \%$ (26.6-52.7)] when compared to febrile [Median (IQR)- $5.98 \%$ (2.98-9.72)] and normal controls [Median (IQR)- $4.48 \%$ (2.57-5.59)], $p<0.01$ (Fig. 2 a). Median (IQR) absolute monocyte counts of children with KD and febrile controls were 1327.5/cu.mm (937.5, $1515.25)$ and $1184 /$ cu.mm $(880,2160)$, respectively ( $p=$ 0.83). Median (IQR) MPA counts of patients with KD was $530.74 /$ cu.mm $(408.87,614.37)$ compared to $96.39 /$ cu.mm $(25.08,121.57)$ in febrile controls, which was statistically significant $(p<0.001)$. A significant drop in MPA\% was noted after IVIg therapy. Serial MPA\% in patients with KD showed a consistent drop in values from the time of diagnosis until the 3rd month of follow-up (Fig. 2b c).

No change in trend of fall of MPA\% was noted even after exclusion of patients who were continued on aspirin (Fig. 2d). MPA\% values at 3 months post-diagnosis of KD [Median (IQR)- $7.55 \%$ (4.15-14.6)] were higher compared to normal controls [Median (IQR)- $4.48 \%$ (2.57-5.59)], $p-0.072$.

No significant differences in MPA\% were noted between patients with and without CAAs (Table 2). There was also no significant difference in MPA\% values between patients with complete and incomplete presentation of KD (Table 3). Median (IQR) MPA\% in children with $\mathrm{KD}$ with fever duration $\leq 10$ days $(n=5)$ was $38.18 \%(31.7,49.5)$ compared to $44.4 \%(31.7,53)$ in children with fever duration $>10$ days $(n=9)$, which is not statistically significant $(p=0.79)$.
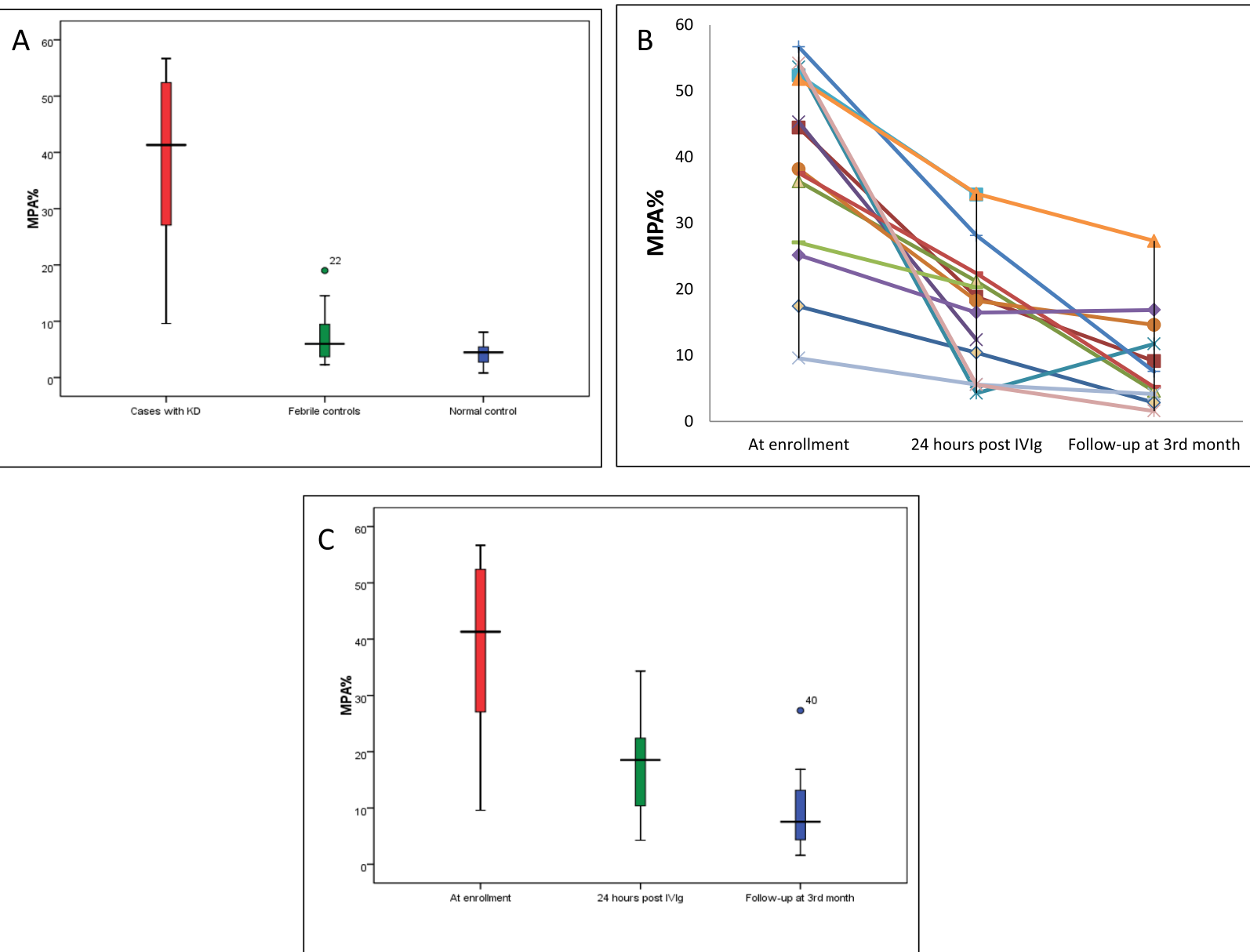

Fig. 2 a. Boxplot showing MPA\% between children with KD at enrolment $(n=14)$ [Median (IQR)- 41.3 (26.6-52.7)], febrile controls $(n=15)$ [Median (IQR)- 5.98 (2.98-9.72)], and normal controls $(n=13)$ [Median (IQR)- $4.48(2.57-5.59)], p<0.001 ; \mathbf{b}$. Trend of serial values MPA\% among all 14 children with KD;c. Boxplot showing MPA\% between cases at enrolment $(n=14)$ [Median (IQR)- 41.31 (26.6-52.69)], $24 \mathrm{~h}$ post-IVlg $(n=14)$ [Median (IQR)- 18.55 (9.2-22.99)], and at 3rd month follow-up $(n=11)$ [Median (IQR)- 7.55 (4.15-14.6)], $p<0.001$; 
Table 2 Median percentage values of MPA (CD14 + CD41+) between children with KD patients with and without coronary artery abnormalities (CAA)

\begin{tabular}{lccc}
\hline Category & Children with CAA $(\boldsymbol{n}=\mathbf{3})$ & Children without CAA $(\boldsymbol{n}=\mathbf{1 1})$ & $\boldsymbol{P}$ value \\
\hline At enrolment [median (Range)] & $38.18(17.42-56.67)$ & $44.44(9.58-54.2)$ & 1.000 \\
$24 \mathrm{~h}$ after IVlg [median (Range)] & $18.26(10.4-28.13)$ & $18.84(4.27-34.32)$ & 0.885 \\
Follow-up at 3rd month [median (Range)] & $7.55(2.84-14.6)$ & $7.17(1.59-27.32)$ & 0.921 \\
\hline
\end{tabular}

\section{Discussion}

Platelet function abnormalities in KD were first reported by Yamada et al. in 1978 [14]. Studies in platelet activation markers in KD have subsequently been undertaken in Japan, USA, and Italy (Table 4). Genetic risk factors and clinical presentation of $\mathrm{KD}$ differ among various populations and ethnicities. Hence platelet reactivity in KD can also be expected to be different in different populations. The important differences in clinical presentation of KD at Chandigarh, North India observed were the relatively higher rates of KD in children $>5$ years of age compared to other population, and the relatively earlier occurrence of periungual peeling and thrombocytosis during acute phase of illness [2]. Present study has been undertaken to analyse one of the most sensitive platelet activation markers, i.e. MPAs, by flow cytometry in a North Indian cohort of KD. To the best of our knowledge, MPAs has not been studied in acute and subacute phases of KD till date, and our study is perhaps the first attempt along these lines.

Levels of MPA\% were found to be significantly elevated in children with $\mathrm{KD}$ compared to febrile controls and healthy controls in our study (median levels of $41.3 \%, 5.98 \%$, and $4.48 \%$ respectively, $p<0.001$ ). MPA\% levels significantly decreased after treatment with IVIg (median: $41.3 \%$ vs. $18.5 \%, p<0.001$ ) [Fig. 2]. Elevations in MPA\% suggest excess activation of platelets in KD compared to other common childhood febrile illnesses. Previous studies report that other platelet activation markers (e.g. neutrophil-platelet aggregates, plateletderived microparticles, platelet VEGF levels, betathromboglobulin levels, PF4 levels, and platelet CD62P expression) are also elevated in acute phase of KD [7-13]. Our study had a high proportion of children with incomplete KD (35.7\%), which is in line with other recent studies from Asia $[15,16]$. Median duration of fever in our cohort of children with KD was 13.5 days that is higher compared to the European and North American cohorts $[17,18]$. Duration of fever may have impacted MPA\% values in children with $\mathrm{KD}$, as most of our patients were diagnosed more than 10 days after the disease onset when the platelet counts begin to increase. However, comparison of MPA\% between children with fever duration $\leq 10$ days and $>10$ days did not show any statistically significant difference. Ueno et al. studied neutrophil-platelet aggregates (NPAs) in Japanese children with KD who had a median duration of fever of 4 days and had shown that NPAs\% levels were significantly higher in KD compared to febrile controls [11].

Median levels of MPA\% on follow-up at 3 months were lower compared to levels measured $24 \mathrm{~h}$ after IVIg therapy, but higher than values obtained in age and sexmatched controls. It suggests that patients with KD may have a prolonged endotheliitis even after control of systemic inflammation with IVIg therapy. Laurito et al. analyzed MPAs in patients with KD several years after the acute phase (mean interval- 76 months). Authors reported that CD41 expression at baseline and after ADP stimulation was significantly higher in patients compared to controls. However, MPA\% levels were not significantly different between two populations [9]. In a recent study by Yahata et al., platelet-derived microparticles were found to have rebound elevations in 8 of $14 \mathrm{pa}$ tients with $\mathrm{KD}$ after discontinuation of aspirin [10]. In our study also, we found rebound elevation in MPA\% levels in 2 patients at 3 months of follow-up. However, majority of patients had lower levels even after discontinuation of aspirin.

Ueno et al. reported that levels of NPAs were significantly higher in patients with CAAs when compared with patients without CAAs [11]. In our study, levels of MPA\% were not different between patients with CAAs $(n=3)$ and those without CAAs $(\mathrm{n}=11)$. Apparent discrepancy in results could be explained by differences in

Table 3 Median percentage values of MPA (CD14 CD41+) between children with complete $(n=8)$ and incomplete KD $(n=6)$

\begin{tabular}{lccc}
\hline Category & Children with complete KD $(\boldsymbol{n}=\mathbf{9})$ & Children with incomplete KD $(\boldsymbol{n}=\mathbf{5})$ & $\boldsymbol{P}$ value \\
\hline At enrolment [median (Range)] & $45.3(27.08-56.67)$ & $25.17(9.58-53.62)$ & 0.083 \\
$24 \mathrm{~h}$ after IVlg [median (Range)] & $20.28(5.56-34.32)$ & $10.4(4.27-22.4)$ & 0.112 \\
Follow-up at 3rd month [median (Range)] & $8.34(1.59-27.32)$ & $5.21(2.84-16.87)$ & 0.792 \\
\hline
\end{tabular}


Table 4 Comparison of studies on platelet functions in Kawasaki disease reported in English literature

\begin{tabular}{|c|c|c|c|}
\hline $\begin{array}{l}\text { Study, year, } \\
\text { and } \\
\text { Country }\end{array}$ & $\begin{array}{l}\text { Platelet activation } \\
\text { marker studied }\end{array}$ & Study population characteristics & Comments \\
\hline $\begin{array}{l}\text { Yokoyama } \\
\text { et al. (1980) } \\
\text { Japan [8] }\end{array}$ & $\begin{array}{l}\text { Platelet aggregation by } \\
\text { optical density method }\end{array}$ & $\begin{array}{l}23 \text { patients with } K D \text { (Age range: } 3 \text { months- } 6 \\
\text { years; } M: F=14: 9 \text { ); }\end{array}$ & $\begin{array}{l}\text { Platelet aggregation in patients with untreated KD }(82.4 \pm \\
11.6 \%) \text { significantly higher than normal controls }(69 \pm 5 \%) \\
\text { and patients with KD treated with low dose aspirin }(66.8 \pm \\
9.6 \%) \text {. Platelet aggregation increased from } 2 \text { nd week of } \\
\text { illness. }\end{array}$ \\
\hline $\begin{array}{l}\text { Burns et al. } \\
\text { (1984) USA } \\
\text { [12] }\end{array}$ & $\begin{array}{l}\text { Plasma beta- } \\
\text { thromboglobulin }\end{array}$ & 31 patients with $\mathrm{KD}$ & $\begin{array}{l}\text { Levels significantly higher in patients with coronary } \\
\text { aneurysms compared to patients without aneurysms } \\
\text { measured } 3 \text { weeks after fever ( } 72.3 \mathrm{ng} / \mathrm{ml} \text { vs. } 29.4 \mathrm{ng} / \mathrm{ml} \\
\text { respectively, } p<0.002) \text {. }\end{array}$ \\
\hline $\begin{array}{l}\text { Taki et al. } \\
\text { (2003) } \\
\text { Japan [7] }\end{array}$ & $\begin{array}{l}\text { Platelet aggregation by } \\
\text { particle counting } \\
\text { method (mV count) }\end{array}$ & $\begin{array}{l}104 \text { children with } \mathrm{KD} \text { (mean age: } 2.1 \pm 1.9 \text { years; } \\
\mathrm{M}: \mathrm{F}=15: 11 \text { ); } 9 \text { normal controls }\end{array}$ & $\begin{array}{l}\text { Spontaneous platelet aggregation was higher in patients } \\
\text { with } \mathrm{KD}\left(46.6 \times 10^{3} \pm 13.2 \times 10^{3}\right) \text { compared to normal } \\
\text { subjects }\left(9.4 \times 10^{3} \pm 3 \times 10^{3}\right) \text {. It reduced significantly after } \\
\text { IVlg therapy }\left(22.8 \times 10^{3} \pm 6.6 \times 10^{3}\right) \text {. }\end{array}$ \\
\hline $\begin{array}{l}\text { Ueno et al. } \\
\text { (2009) } \\
\text { Japan [13] }\end{array}$ & Platelet VEGF by ELISA & $\begin{array}{l}80 \text { patients with } \mathrm{KD} \text { (Mean age: } 2.1 \pm 1.8 \text { years, } \\
\mathrm{M}: \mathrm{F}=43: 37) ; 26 \text { controls }\end{array}$ & $\begin{array}{l}\text { Levels significantly high in } \mathrm{KD}\left(18.8 \pm 10.1 \times 10^{-8} \mathrm{pg}\right) \\
\text { compared to controls }\left(8.1 \pm 3.0 \times 10^{-8} \mathrm{pg}\right) \text {. The levels } \\
\text { decreased in IVlg responders and remained elevated in } \\
\text { IVlg non-responders. }\end{array}$ \\
\hline $\begin{array}{l}\text { Yahata et al. } \\
\text { (2014) Japan } \\
\text { [10] }\end{array}$ & $\begin{array}{l}\text { Platelet derived } \\
\text { microparticles by ELISA }\end{array}$ & $\begin{array}{l}18 \text { patients with acute KD (mean age: } 2 \text { years } \\
7 \text { months) in whom } 14 \text { received IVlg therapy; } \\
33 \text { children as febrile controls }\end{array}$ & $\begin{array}{l}\text { Levels were significantly high in acute phase of } \mathrm{KD}(43.9 \pm \\
13.5 \mathrm{U} / \mathrm{ml}) \text { compared to febrile controls }(15.4 \pm 6.8 \mathrm{U} / \mathrm{ml}) \text {. } \\
\text { The levels significantly came down with } \mathrm{IVIg} \text { therapy and } \\
\text { it rebounded after discontinuation of aspirin in } 8 \text { patients. }\end{array}$ \\
\hline $\begin{array}{l}\text { Laurito et al. } \\
\text { (2014) Italy } \\
\text { [9] }\end{array}$ & $\begin{array}{l}\text { Monocyte platelet } \\
\text { aggregates by flow } \\
\text { cytometry }\end{array}$ & $\begin{array}{l}14 \text { patients with past history of } \mathrm{KD} \text { (mean } \\
\text { follow-up: } 76 \pm 58 \text { months; } \mathrm{M}: \mathrm{F}=9: 5) ; 14 \\
\text { controls }\end{array}$ & $\begin{array}{l}\text { Mean \%MPAs were similar in patients and controls even } \\
\text { after ADP stimulation }(18.3 \pm 1.9 \% \text { vs. } 17.2 \pm 1.5 \% \text {; } p= \\
0.09) \text {. CD41 expression in MPA gate was higher in KD than } \\
\text { controls after ADP stimulation ( } 19.3 \pm 1.3 \% \text { vs. } 17 \pm 1.7 \\
p<0.001) \text {; }\end{array}$ \\
\hline $\begin{array}{l}\text { Ueno et al. } \\
\text { (2015) } \\
\text { Japan [11] }\end{array}$ & $\begin{array}{l}\text { Neutrophil-platelet } \\
\text { aggregates by flow } \\
\text { cytometry }\end{array}$ & $\begin{array}{l}40 \text { patients with } \mathrm{KD} \text { (median age: } 1.75 \text { years, } \mathrm{M}: \\
\mathrm{F} \approx 1: 1) ; 7 \text { febrile controls, and } 9 \text { normal } \\
\text { controls }\end{array}$ & $\begin{array}{l}\text { Percentage of neutrophil-platelet aggregates were signifi- } \\
\text { cantly high in KD compared to febrile and normal controls. } \\
\text { Rate of decrease in aggregates was significantly high in } \\
\text { patients who received prednisolone + IVlg compared to } \\
\text { patients who had received IVIg alone. }\end{array}$ \\
\hline $\begin{array}{l}\text { Present } \\
\text { study (2019) } \\
\text { India }\end{array}$ & $\begin{array}{l}\text { Monocyte platelet } \\
\text { aggregates by flow } \\
\text { cytometry }\end{array}$ & $\begin{array}{l}14 \text { patients with acute } \mathrm{KD} \text { (Median age: } 6 \text { years; } \\
\text { M:F=6:1); } 15 \text { febrile controls and } 13 \text { normal } \\
\text { controls }\end{array}$ & $\begin{array}{l}\text { Median \%MPA significantly higher in KD compared to } \\
\text { febrile and normal control ( } 41.3 \text { vs. } 5.9 \text { vs. } 4.5 \% ; p<0.001) \text {. } \\
\text { Levels significantly came down } 24 \text { h after IVIg therapy } \\
(18.6 \% ; p<0.001) \text {. }\end{array}$ \\
\hline
\end{tabular}

KD Kawasaki Disease; MPA Monocyte-platelet aggregates; IVIg Intravenous immunoglobulin; VEGF Vascular endothelial growth factor; ELISA Enzyme linked immunosorbent assay; ADP Adenosine diphosphate

ethnicities of the study populations, small sample size in both studies, and differences in methodology of assessment of platelet activation. Ueno et al. also reported that levels of neutrophil-platelet aggregates were significantly lower in patients with KD treated with both IVIg and oral prednisolone than in patients who received IVIg alone [11]. Corticosteroids were not used in any patients in our cohort.

A limitation of our study is the small sample size. This is understandable considering the fact that the protocol had to be completed in a limited span of time. Being a single centre study, there was uniformity in diagnosis and treatment protocols followed for management. Efforts were put in to standardize laboratory assays for MPAs before commencement of the study. We could use only single surface marker-CD14 for identification of monocytes in our study, as it is expressed both in classical and non-classical monocytes [19]. CD14 can also be weakly expressed in some neutrophils and B cells, so, monocytes alone may not have been accurately captured in our experiment. Use of an imaging flow cytometry could have precisely showed the aggregates of monocytes and platelets [20], however, we could not use this modality in our study. Our patient cohort had a high proportion of children with KD who had fever of more than 10 days duration (64.3\%). More studies are needed in future to decipher the platelet activation status in early stages of KD.

To conclude, MPA\% was significantly elevated in our cohort of children with KD when compared with age and sex-matched febrile and healthy controls. Future long-term studies are warranted to find out whether elevated MPAs in KD would have any clinical implications. This may provide a theoretical basis 
for additional immunosuppressive and/or antiplatelet therapy in KD.

\section{Abbreviations}

KD: Kawasaki disease; MPA: Monocyte-platelet aggregates; IVlg: Intravenous immunoglobulin; CAD: Coronary artery disease; AHA: American Heart Association

\section{Acknowledgements}

Nil

\section{Authors' contributions}

PV, SS, MS, JA- Inception of idea; PV, AR, JS- Carried out the flow cytometry experiments; PV- Literature review and framing of first draft; JA, SS, MS, ARCritical review and editing of the manuscript; PV, SS- Editing of manuscript and final approval. The author(s) read and approved the final manuscript.

\section{Funding}

This work was partly supported by a Special research grant for MD/MS/DM/ MCh from PGIMER, Chandigarh, India.

\section{Availability of data and materials}

The datasets used and/or analyzed during the current study are available from the corresponding author on reasonable request.

\section{Declarations}

Ethical approval and consent to participate:

All procedures performed in studies involving human participants were in accordance with the ethical standards of the Institutional and National Research Committee and with the 1964 Helsinki declaration and its later amendments or comparable ethical standards. Informed consent was obtained from parents of all individual participants included in the study.

\section{Consent for publication}

All authors consent for final approval and inclusion of co-authors for this manuscript.

\section{Authors' information}

The study was presented in the 24th European Pediatric Rheumatology Congress held at Athens, Greece and the abstract was published in the conference proceedings.

Ref: Proceedings of the 24th Paediatric Rheumatology European Society Congress: Part one. Pediatr Rheumatol Online J 2017;15(Suppl 2):64.

\section{Competing interests}

All authors declare that he/she has no potential conflict of interest.

\section{Author details}

${ }^{1}$ Allergy Immunology Unit, Department of Pediatrics, Advanced Pediatrics Centre, Postgraduate Institute of Medical Education and Research, 160012 Chandigarh, India. ${ }^{2}$ Department of Hematology, Postgraduate Institute of Medical Education and Research, 160012 Chandigarh, India.

\section{Received: 30 June 2020 Accepted: 4 March 2021}

\section{Published online: 12 March 2021}

\section{References}

1. Newburger JW, Takahashi M, Gerber MA, Gewitz MH, Tani LY, Burns JC, et al. Diagnosis, treatment, and long-term management of Kawasaki disease: a statement for health professionals from the Committee on Rheumatic Fever, Endocarditis and Kawasaki Disease, Council on Cardiovascular Disease in the Young, American Heart Association. Circulation. 2004;110:2747-71.

2. Singh S, Aulakh R, Bhalla AK, Suri D, Manojkumar R, Narula N, Burns JC. Is Kawasaki disease incidence rising in Chandigarh, North India? Arch Dis Child. 2011:96:137-40.

3. Orenstein JM, Shulman ST, Fox LM, Baker SC, Takahashi M, Bhatti TR, et al. Three linked vasculopathic processes characterize Kawasaki disease: a light and transmission electron microscopic study. PLoS One. 2012;7:e38998.
4. Chatterjee M, Geisler T. Inflammatory Contribution of Platelets Revisited: New Players in the Arena of Inflammation. Semin Thromb Hemost. 2016;42: 205-14.

5. Furman Ml, Benoit SE, Barnard MR, Valeri CR, Borbone ML, Becker RC, et al. Increased platelet reactivity and circulating monocyte-platelet aggregates in patients with stable coronary artery disease. J Am Coll Cardiol. 1998;31:352-8.

6. Gerrits AJ, Frelinger AL, Michelson AD. Whole Blood Analysis of LeukocytePlatelet Aggregates. Curr Protoc Cytom. 2016;78:6.

7. Taki M, Kobayashi M, Ohi C, Shimizu H, Goto K, Aso K, et al. Spontaneous platelet aggregation in Kawasaki disease using the particle counting method. Pediatr Int. 2003:45:649-52.

8. Yokoyama $\mathrm{T}$, Kato $\mathrm{H}$, Ichinose $\mathrm{E}$. Aspirin treatment and platelet function in Kawasaki disease. Kurume Med J. 1980;27:57-61.

9. Laurito M, Stazi A, Delogu AB, Milo M, Battipaglia I, Scalone G, et al. Endothelial and platelet function in children with previous Kawasaki disease. Angiology. 2014;65:716-22.

10. Yahata T, Suzuki C, Yoshioka A, Hamaoka A, Ikeda K. Platelet activation dynamics evaluated using platelet-derived microparticles in Kawasaki disease. Circ J. 2014;78:188-93.

11. Ueno K, Nomura Y, Morita Y, Eguchi T, Masuda K, Kawano Y. Circulating platelet-neutrophil aggregates play a significant role in Kawasaki disease. Circ J. 2015:79:1349-56.

12. Burns JC, Glode MP, Clarke SH, Wiggins J, Hathaway WE. Coagulopathy and platelet activation in Kawasaki syndrome: Identification of patients at high risk for development of coronary artery aneurysms. J Pediatr. 1984;105:206-11.

13. Ueno K, Nomura Y, Hashiguchi T, Masuda K, Morita Y, Hazeki D, et al. Platelet vascular endothelial growth factor is a useful predictor for prognosis in Kawasaki syndrome. Br J Haematol. 2010;148:285-92.

14. Yamada K, Fukumoto T, Shinkai A, Shirahata A, Meguro T. The platelet functions in acute febrile mucocutaneous lymph node syndrome and a trial of prevention for thrombosis by antiplatelet agent. Nihon Ketsueki Gakkai Zasshi. 1978;41:791-802.

15. Xie LP, Yan WL, Huang M, Huang MR, Chen $S$, Huang GY, et al. Epidemiologic Features of Kawasaki Disease in Shanghai From 2013 Through 2017. J Epidemiol. 2019 Sep 21. doi:https://doi.org/10.2188/jea.JE2 0190065. Epub ahead of print.

16. Kim GB, Park S, Eun LY, Han JW, Lee SY, Yoon KL, et al. Epidemiology and Clinical Features of Kawasaki Disease in South Korea, 2012-2014. Pediatr Infect Dis J. 2017:36:482-85.

17. Skochko SM, Jain S, Sun X, Sivilay N, Kanegaye JT, Pancheri J, et al. Kawasaki Disease Outcomes and Response to Therapy in a Multiethnic Community: A 10-Year Experience. J Pediatr 2018;203:408 - 15.e3.

18. Tulloh RMR, Mayon-White R, Harnden A, Ramanan AV, Tizard EJ, Shingadia $D$, et al. Kawasaki disease: a prospective population survey in the UK and Ireland from 2013 to 2015. Arch Dis Child. 2019;104:640-46.

19. Ong SM, Teng K, Newell E, Chen H, Chen J, Loy T, et al. A Novel, FiveMarker Alternative to CD16-CD14 Gating to Identify the Three Human Monocyte Subsets. Front Immunol. 2019:10:1761

20. Hui H, Fuller KA, Erber WN, Linden MD. Imaging flow cytometry in the assessment of leukocyte-platelet aggregates. Methods. 2017;112:46-54.

\section{Publisher's Note}

Springer Nature remains neutral with regard to jurisdictional claims in published maps and institutional affiliations.

\section{Ready to submit your research? Choose BMC and benefit from:}

- fast, convenient online submission

- thorough peer review by experienced researchers in your field

- rapid publication on acceptance

- support for research data, including large and complex data types

- gold Open Access which fosters wider collaboration and increased citations

- maximum visibility for your research: over $100 \mathrm{M}$ website views per year

At BMC, research is always in progress.

Learn more biomedcentral.com/submissions 